IZA DP No. 5781

The Kid's Speech:

The Effect of Stuttering on Human Capital Acquisition

Daniel I. Rees

Joseph J. Sabia

June 2011 


\title{
The Kid's Speech: The Effect of Stuttering on Human Capital Acquisition
}

\author{
Daniel I. Rees \\ University of Colorado Denver \\ and IZA \\ Joseph J. Sabia \\ San Diego State University
}

\section{Discussion Paper No. 5781 \\ June 2011}

\author{
IZA \\ P.O. Box 7240 \\ 53072 Bonn \\ Germany \\ Phone: +49-228-3894-0 \\ Fax: +49-228-3894-180 \\ E-mail: iza@iza.org
}

Any opinions expressed here are those of the author(s) and not those of IZA. Research published in this series may include views on policy, but the institute itself takes no institutional policy positions.

The Institute for the Study of Labor (IZA) in Bonn is a local and virtual international research center and a place of communication between science, politics and business. IZA is an independent nonprofit organization supported by Deutsche Post Foundation. The center is associated with the University of Bonn and offers a stimulating research environment through its international network, workshops and conferences, data service, project support, research visits and doctoral program. IZA engages in (i) original and internationally competitive research in all fields of labor economics, (ii) development of policy concepts, and (iii) dissemination of research results and concepts to the interested public.

IZA Discussion Papers often represent preliminary work and are circulated to encourage discussion. Citation of such a paper should account for its provisional character. A revised version may be available directly from the author. 


\section{ABSTRACT \\ The Kid's Speech: The Effect of Stuttering on Human Capital Acquisition ${ }^{*}$}

A number of studies have shown that childhood speech impairments such as stuttering are associated with lower test scores and educational attainment. However, it is unclear whether this result is causal in nature or whether it can be explained by difficult-to-measure heterogeneity at the community, family, or individual level. Using data from the National Longitudinal Study of Adolescent Health and ordinary least squares, we show that stuttering is negatively associated with high school grades, the probability of high school graduation, and the probability of college attendance. However, empirical specifications with family fixed effects or controls for learning disabilities such as Attention Deficit Hyperactivity Disorder suggest that these associations can, in large part, be explained by difficult-to-measure heterogeneity.

JEL Classification: I1, I2

Keywords: $\quad$ speech impairment, stuttering, human capital, educational attainment

Corresponding author:

Daniel I. Rees

University of Colorado Denver

Department of Economics

CB 181, P.O. Box 173364

Denver, CO 80217-3364

USA

E-mail: Daniel.Rees@ucdenver.edu

\footnotetext{
* The authors thank Hani Mansour and participants at the 2010 Southern Economic Association for useful comments and suggestions on an earlier draft of this paper. This research uses data from the National Longitudinal Study of Adolescent Health, designed by J. Richard Udry, Peter S. Bearman, and Kathleen Mullan Harris, and funded by a grant P01-HD31921 from the National Institute of Child Health and Human Development, with cooperative funding from 17 other agencies. Special acknowledgment is due Ronald R. Rindfuss and Barbara Entwisle for assistance in the original design. Persons interested in obtaining data files from the National Longitudinal Study of Adolescent Health should contact Add Health, Carolina Population Center, 123 W. Franklin Street, Chapel Hill, NC 27516-2524 (http://www.cpc.unc.edu/addhealth/contract.html).
} 


\section{INTRODUCTION}

Recently, economists have begun to explore the extent to which chronic childhood and adolescent health conditions such as Attention Deficit Hyperactivity Disorder (Currie and Stabile 2006; Fletcher and Wolfe 2008), depression (Fletcher 2010), migraine headache (Rees and Sabia 2011; Sabia and Rees forthcoming), and obesity (Sabia 2007; Kaestner and Grossman 2009) interfere with the acquisition of human capital. The current study adds to this fast-growing literature by using data from the National Longitudinal Study of Adolescent Health (Add Health) to estimate the effects of stuttering, a common speech impairment, on academic performance and educational attainment.

There is a large body of work showing that speech impairments are associated with sharply lower scores on tests of reading and math (Catts 1993; Walker et al. 1994; Stothard et al. 1998; Catts et al. 2002; Knox 2002; Nathan et al. 2004; Catts et al. 2008; Harrison et al. 2009; Eide and Showalter 2010; Law et al. 2010). There is also evidence, albeit weaker, that children with speech impairments go on to receive fewer years of education than their counterparts without speech impairments (Snowling et al. 2001; Johnson et al. 2010). The results of these studies could indicate that speech impairments lead, in a causal sense, to reduced academic performance and educational attainment. However, most studies in this area have used non-representative samples, and, to our knowledge, none have attempted to account for the potential influence of unobservables. Thus, there exists the possibility that their results were driven by difficult-to-measure factors at the level of the community, family or individual. 
The Add Health data are nationally representative and contain detailed information on the behavior, personality, and family background of respondents. This richness allows us to observe, and control for, a much wider variety of potentially confounding factors than were available to the majority of previous researchers. In addition, by comparing the experiences of siblings with discordant stuttering experiences, we are able to control for family-level unobservables such as parental involvement. Finally, there is evidence that ADHD and other learning disabilities such as dyslexia are associated with stuttering (Blood and Seider 1981; Arndt and Healey 2001; Blood et al. 2003; Blood et al. 2009; Ajdacic-Gross et al. 2010). Because the Add Health asked questions aimed at assessing whether respondents had a learning disability such as Attention Deficit Hyperactivity Disorder (ADHD) or dyslexia, we are able to explore whether these factors help explain the relationship between stuttering and the outcomes under study.

Our baseline ordinary least squares (OLS) estimates are consistent with the findings of previous studies: respondents who reported having a problem with stuttering tend to have lower grades than their counterparts who did not report a problem with stuttering. Stuttering is also associated with a lower probability of graduating high school and a lower probability of attending college. However, when we restrict our sample to full biological siblings (including twins) and add family fixed effects, these associations become much smaller in magnitude, suggesting that family-level unobservables play an important role. Moreover, when we control for a history of ADHD or the presence of another learning disability, the estimated effects of stuttering shrink dramatically and become statistically indistinguishable from zero at conventional levels. These findings 
suggest that the impact of stuttering on human capital acquisition is much weaker than previously argued.

\section{BACKGROUND}

\subsection{Definition, prevalence, incidence, and causes of stuttering}

Stuttering (also known as stammering) is a speech disorder in which sounds, syllables or words are repeated or prolonged, disrupting the flow of speech. It typically begins early in life, and can be accompanied by eye-blinking, head jerks and facial grimaces. ${ }^{1}$ Sufferers sometimes avoid specific words, speak in a rapid monotone, or even adopt an accent in order to keep from stuttering. Most children who stutter eventually outgrow it, but some do not.

Estimates of the lifetime incidence of stuttering range from 4 percent to as high as 8.5 percent (Mansson 2000; Gordon 2002; Reilly et al. 2009). ${ }^{2}$ The prevalence of stuttering among all adults in the United States is approximately one percent (Kang et al. 2010), and estimates of prevalence among children and adolescents are typically on the order of one to two percent, but are often based on non-representative samples (Craig and Tran 2005). ${ }^{3}$

\footnotetext{
${ }^{1}$ When first onset is before adolescence, it is called developmental stuttering; when caused by trauma to the brain, it is called acquired stuttering (Craig and Tran 2006).

${ }^{2}$ Incidence refers to the percentage of the population under study who stuttered at some point in their lives. Prevalence refers to the percentage of the population under study who stutter at a given point in time. Most studies have found incidence rates on the order of 4 percent (Gordon 2002, p. 278). However recent work suggests that the incidence of stuttering may be higher than 4 percent. For instance, Mansson (2000) found that the incidence of stuttering among children from the Danish island of Bornholm was 5.2 percent; Reilly et al. (2009) found that the incidence of stuttering among children living in Melbourne Australia was 8.5 percent.

${ }^{3}$ A recent analysis of data from the 2003 National Survey of Children's Health found much higher prevalence rates among U.S. children and adolescents, but grouped other types of speech impairments with
} 
Researchers once thought that stuttering could be caused by parental speech patterns (Nippold and Rudzinski 1995). Although this hypothesis has fallen out of favor, the exact causes of stuttering are still a mystery (Viswanath et al. 2004). There is strong evidence based on studies of twins and adoptees (Felsenfeld and Plomin1997; Felsenfeld et al. 2000; Ooki S. 2005; Dworzynski et al. 2007) that stuttering can be inherited, and recent work by Kang et al. (2010) has in fact pinpointed several gene mutations that appear to be directly linked to stuttering. However, these mutations account for, at most, only a small fraction of the total number of stutterers in the general population (Kang et al. 2010, p. 684).

\subsection{Why might stuttering be related to the outcomes under study?}

In an often-cited article, Bashir and Scavuzzo (1992) discussed why speech impairments might lead to academic problems. They noted that "language facilitates social relations and cultural membership" (p. 54), and argued that these are important inputs to the production of knowledge. ${ }^{4}$ In addition, they argued that children and adolescents whose use of language is impaired are likely to be treated differently by teachers, and may suffer from a reluctance to ask questions and provide feedback in the classroom.

Subsequent researchers have found that adolescents who stutter are indeed more likely to be teased or bullied at school (Langevin and Hagler 2004; Blood and Blood

stuttering and stammering. The results of this analysis are available at: http://www.nidcd.nih.gov/health/statistics/vsl/problems.htm

\footnotetext{
${ }^{4}$ In a similar vein, Craig and Tran (2006, p. 64) noted that, "as children who stammer grow into adolescence and adulthood, the risk increases that chronic negative experiences associated with the disorder will precipitate the development of shyness and social avoidance behaviour, limiting opportunities for psychological and educational development."
} 
2004; Blood and Blood 2007), and more likely to have difficulties establishing and maintaining friendships (Davis et al. 2002). There is also evidence that they are more likely to suffer from anxiety (Craig et al. 2003; Blood et al. 2007; Mulcahy et al. 2008), but it is not clear whether school attendance exacerbates this problem. ${ }^{5}$ Finally, there is evidence, albeit largely descriptive in nature, that teachers and school administers associate stuttering with negative personality traits such as shyness, and may expect less of their students who stutter (Yeakle and Cooper 1986; Lass et al. 1992; Lass et al. 1994; Ruscello et al. 1994; Dorsey and Guenther 2000).

Although far from conclusive, the results of these studies suggest that stuttering could be causally related to our outcomes through at least two potential routes: (1) to the extent that it directly interferes with learning, or restricts occupational choice, stuttering can be thought of as reducing the return to schooling; and (2) stuttering can be thought of as raising the cost of schooling or, in fact, of engaging in other social activities such as playing a team sports or participating in a club.

\section{DATA AND MEASURES}

\subsection{The data}

The data used in this study come from the National Longitudinal Study of Adolescent Health (Add Health), which was conducted by the Carolina Population Center at the University of North Carolina at Chapel Hill. The Add Health data collection effort began with the identification of more than 26,000 high schools from across the United States. Eighty were selected with probability proportional to enrollment, stratified by

\footnotetext{
${ }^{5}$ Interestingly, children who stutter do not seem to have elevated levels of anxiety, suggesting that anxiety is a result, not a cause, of stuttering (Hancock et al. 1998; Craig and Tran 2006).
} 
region of the country, level of urbanization, type (public vs. private), and racial mix. Twenty of these 80 high schools enrolled $7^{\text {th }}$ graders, but if a high school did not enroll $7^{\text {th }}$ graders it was matched with a "feeder school" (that is, a junior high or middle school). Fifty-two feeder schools were recruited, bringing the total number of participating schools to 132 .

The Wave I (baseline) in-home survey was administered between April and December of 1995 to a core sample composed of 12,105 students who were selected at random from the rosters of the 132 participating schools. The core sample was augmented through a special effort to collect information on siblings, half-siblings, and twins living in the same household as one of the 12,105 students selected at random from the school rosters. In addition, the entire population of students in 16 of the 132 participating schools was administered the Wave I in-home survey, and a number of “supplementary samples" were drawn. All told, the Wave I in-home survey was administered to 20,745 respondents. When weighted, it can be used to produce nationally representative statistics for $7^{\text {th }}$ to $12^{\text {th }}$ graders living in the United States in 1995 (Harris et al. 2008).

Three follow-ups have been conducted since the initial Add Health data collection effort. The first follow-up, the Wave II in-home survey, was conducted in 1996, approximately one year after the baseline survey. The second follow-up, the Wave III inhome survey, was administered in 2001 . It contains information on 15,170 of the original Add Health participants, who were between the ages of 18 and 28 when they were interviewed. Our focus is on the 13,549 individuals at Wave III who were at least 20 
years of age and provided sufficient information to construct the key measures described in the next section. ${ }^{6}$

\subsection{The measures}

Past studies of stuttering prevalence have typically relied on formal diagnoses made by health care professionals or evaluations performed by an interviewer with experience in treating and diagnosing stuttering (Craig et al. 2002). In contrast, at Waves III and IV, the Add Health simply asked respondents if they had "a problem" with stuttering or stammering. ${ }^{7}$ Seven percent answered this question in the affirmative at Wave III, suggesting that there were respondents who would not have been formally diagnosed as having impaired speech by a doctor, but nevertheless felt as though they struggled with stuttering or had struggled with stuttering at some point during their lives. ${ }^{8}$ Because the onset of stuttering rarely occurs in adulthood, it is safe to assume that the vast majority of these respondents suffered from developmental as opposed to acquired stuttering, which can occur as a result of stroke or trauma (Craig and Tran 2006).

By Wave IV, only 4.1 percent of respondents said they "stuttered or stammered," indicating that a sizeable portion were able to master their speech impairment, perhaps

\footnotetext{
${ }^{6} \mathrm{We}$ adopt this age restriction in order to focus on respondents who were old enough to have completed high school and begun college by the time of the Wave III survey.

${ }^{7}$ Specifically, Add Health respondents were asked, "Do you have a problem with stuttering or stammering?"

${ }^{8}$ As noted above, the lifetime incidence of stuttering is much higher than the prevalence (Craig et al. 2002; Gordon 2002), and estimates of lifetime incidence range from 4 to 8.5 percent (Mansson 2000; Gordon 2002; Reilly et al. 2009).
} 
through speech therapy. ${ }^{9}$ Our focus is on the Wave III measure of stuttering. However, when this measure was replaced by an indicator of whether the respondent reported a problem with stuttering at Wave IV, the results were qualitatively unchanged from those discussed below. ${ }^{10}$ Although the measures of stuttering in the Add Health are not ideal, there exists no nationally representative data set containing formal diagnoses of stuttering that would allow us to estimate the empirical models introduced below.

We consider three outcomes below. The first is a measure of academic performance, the respondent's cumulative high school grade point average (GPA), which was calculated using the official transcripts made available to researchers with access to the restricted-use Adolescent Health data. The other two outcomes capture longer-run educational attainment. Specifically, we created a dichotomous variable equal to 1 if the respondent had received a high school diploma by the time of the Wave III survey in 2001 , and equal to 0 if he or she had dropped out of high school. We also generated a dichotomous variable equal to 1 if the respondent was attending college at the time of the Wave III survey or had completed at least one year of college prior to the survey.

The means and standard deviations of our key variables are presented in Table 1. The average GPA in our sample was 2.45. Female respondents had, on average, higher GPAs than their male counterparts (2.69 vs. 2.39). Eighty-two percent of respondents

\footnotetext{
${ }^{9}$ The Add Health does not contain information on whether respondents sought or received treatment for their stuttering.

${ }^{10}$ OLS estimates using the Wave IV stuttering measure are reported in Appendix Table 1. Respondents at Wave IV (but not Wave III) were asked, "How would you describe your stuttering or stammering at this time?" Responses included "severe," "moderate," and "mild." However, only 0.5 percent of respondents reported moderate stuttering and just 0.1 percent reported severe stuttering. Thus, we were unable to estimate the effects of stuttering by severity.
} 
had received a high school diploma by the time of the Wave III survey, and 58.9 percent had attended or completed at least one year of college.

Cross-tabulations presented in the lower half of Table 1 suggest that there is a negative relationship between the variable Stutter (equal to 1 if the respondent reported a problem with stuttering at Wave III and equal to 0 otherwise) and academic performance. Among those with grade point averages of 3.5 or better, 3.1 percent reported a problem with stuttering; among those with GPAs lower than 3.5 , the rate was 7.6 percent. A similar relationship can be seen for our measures of educational attainment. The stuttering rate among high school graduates was 6.5 percent, compared to 9.5 percent among dropouts; the stuttering rate among college attendees was 5.6 percent, compared to 9.0 percent for those who did not attend college.

\section{METHODS}

\subsection{Ordinary least squares}

We begin the empirical analysis by using a simple bivariate regression model to explore whether stuttering is associated with the outcomes discussed above. Specifically, we estimate:

$$
E_{i}=\alpha+\delta \text { Stutter }_{i}+\varepsilon_{i},
$$

where $E_{i}$ is a measure of respondent $i$ 's academic performance or human capital accumulation. Next, we control for individual- and family-level characteristics by adding a vector $\boldsymbol{X}_{\boldsymbol{i}}$ to the right-hand side of the estimating equation: 


$$
E_{i}=\alpha+\delta \text { Stutter }_{i}+\beta^{\prime} \mathbf{X}_{i}+\varepsilon_{i}
$$

The vector $\boldsymbol{X}_{\boldsymbol{i}}$ includes the respondent's age at Wave III, household income, parental educational attainment, parental marital status, urbanicity, region, religiosity, race, appearance, number of biological siblings, whether the respondent had an older sibling, height, weight, region, average class size, school type (public/private), and the percent of students enrolled in college preparatory courses. In addition to the controls listed above, we experiment with controlling for the respondent's score on the Peabody Picture and Vocabulary Test (PPVT), used by prior researchers as a measure of cognitive ability. ${ }^{11}$

\subsection{School fixed effects}

Difficult-to-measure factors at the school or neighborhood level could influence stuttering and academic performance. For example, teaching style or peer behavior could be associated with both stammering and educational outcomes. A solution to this problem is to augment equation (2) with school fixed effects:

$$
E_{i s}=\alpha+\delta \text { Stutter }_{i}+\beta^{\prime} \mathbf{X}_{i}+z_{s}+\varepsilon_{i s},
$$

where $s$ denotes respondent i's middle or high school at the time of the Wave I survey, and $\mathbf{z}_{\mathbf{s}}$ is a vector of school fixed effects.

\footnotetext{
${ }^{11}$ See, for example, Sabia and Rees (2011). Each of our controls, with the exception of age, were measured at Wave I, when the respondents were between the ages of 12 and 21.
} 


\subsection{Propensity score matching}

It is also possible that respondents who stuttered were different from nonstutterers in terms of observable characteristics, but if respondents from the two groups lack common support, then propensity score matching (PSM) should produce more reliable estimates than the standard regression approach (Rosenbaum and Rubin 1983).

In an effort to ensure common support, and in order to control for the influence of school- and community-level factors that could influence both the probability of stuttering and the educational outcomes under study, we estimate a within-school propensity score matching model. Following the approach taken by Levine and Painter (2003), we begin by estimating a probit model of the following form:

$$
\operatorname{Pr}\left\{\text { Forced }_{i s}=1\right\}=1-\Phi\left(-\alpha-z_{s}-\beta^{\prime} \mathbf{X}_{i s}-\gamma^{\prime} F_{i s}\right)
$$

where $s$ denotes the respondent's school, $\mathbf{z}_{\boldsymbol{s}}$ is a vector of school fixed effects, $\boldsymbol{X}_{\boldsymbol{i}}$ is the vector of controls introduced previously, and $\boldsymbol{F}_{\boldsymbol{i}}$ is a vector of additional controls designed to capture the quality of the parent-child relationship: the closeness of the relationship between the respondent and his/her mother and father, and the degree of disappointment the respondent's mother would feel if her child did not graduate from high school or college.

After estimating equation (4), we use nearest neighbor matching without replacement to assign respondents who stutter to a non-stutterer whose estimated propensity score was within 0.003 . In a further effort to ensure common support, we drop stutterers whose estimated propensity score was higher than the maximum or less 
than the minimum estimated propensity score of non-stutterers, and drop the 4.5 percent of respondents who stuttered and whose propensity score was furthest from the propensity score of their match. The within-school propensity score matching (WSPSM) estimates are calculated by comparing the outcomes of stutterers with those of their match. Specifically, they are equal to the mean difference in outcomes between these two groups.

\subsection{Family fixed effects}

While the WSPSM model will ensure common support on observables, as well as control for unmeasured school- and community-level characteristics, it will not control for potentially important, difficult-to-measure confounders at the family level. Therefore, we next restrict the sample to biological siblings (including twins) and estimate:

$$
E_{i j}=\alpha+\delta \text { Stutter }_{i j}+\beta^{\prime} \mathbf{X}_{i}+v_{j}+\varepsilon_{i j}
$$

where $j$ denotes the respondent's family, and $\boldsymbol{v}_{\boldsymbol{j}}$ is a sector of family fixed effects. The observables included on the right-hand side of (5) are: age, race, appearance, religious affiliation, cognitive ability, height, body weight, marital status, and whether the respondent had an older sibling. This approach will ensure that our estimates of the effect of stuttering on human capital acquisition are not influenced by difficult-tomeasure family-level confounders. As robustness check, we estimate (5) restricting our attention to twins. 


\section{THE RESULTS}

The main results appear in Tables 2-7. Standard errors are corrected for clustering at the school level and are in parentheses.

\subsection{Ordinary least squares estimates}

In Table 2, we show OLS estimates of the relationship between stuttering and the outcomes under study. Column (1) presents (bivariate) estimates of $\delta$ from equation (1). They show that stuttering is associated with a 0.240 -point lower grade point average, a 0.067 lower probability of high school graduation, and a 0.126 lower probability of college attendance.

Adding controls for individual and family background characteristics (column 2) reduces the absolute magnitude of $\hat{\delta}$ by 50 percent $(0.119 / 0.240)$ in the GPA equation, 43 percent $(0.029 / 0.067)$ in the high school graduation equation, and 46 percent (0.058/0.126) in the college attendance equation. Controlling for the respondent's PPVT score (column 3) further reduces the estimated association between stuttering and these outcomes. With the full set of controls on the right-hand side, stuttering is associated with a 0.085 -point reduction in GPA, a 0.029 reduction in the probability of high school graduation, and a 0.046 reduction in the probability of college attendance, estimates that are comparable to estimates of the effect of ADHD (Currie and Stabile 2006; Fletcher and Wolfe 2008), major depression (Fletcher 2010), migraine headache (Rees and Sabia 2011), and obesity (Sabia 2007; Kaestner and Grossman 2009). ${ }^{12}$

\footnotetext{
${ }^{12}$ Fletcher and Wolfe (2008) found that ADHD was associated with a 7 to 10 percent reduction in GPA; Fletcher (2010) found that depression was associated with 3.9 percent fewer years of schooling; Sabia (2007) found that obesity was associated with a 6.1 to 11.1 percent reduction in GPA; and Rees and Sabia (2011) found that migraine headache was associated with a 4.6 percent reduction in the probability of high
} 


\subsection{Estimates controlling of school fixed effects}

In Panel I of Table 3 we explore the sensitivity of the estimates discussed above to adding school fixed effects as controls. We find that controlling for community- and school-level unobservables modestly attenuates the estimated effect of stuttering on human capital acquisition. Specifically, stuttering is associated with a 0.068 reduction in GPA, a (statistically insignificant) 0.021 reduction in the probability of high school graduation, and a 0.042 reduction in the probability of college attendance when school fixed effects are included.

In the remaining two panels of Table 3, we explore whether the effect of stuttering on human capital acquisition differs by gender. We find a negative relationship between stuttering and our outcomes for both males and females. For males (Panel II), estimates that include school fixed effects show that stuttering is associated with a 0.062 reduction in GPA, a 0.030 reduction in the probability of high school graduation, and a 0.040 reduction in the probability of college attendance. For females (Panel III), our estimates of the effect of stuttering on GPA and college attendance are of comparable magnitude; the estimated effect of stuttering on high school graduation is smaller in magnitude than that reported in Panel II and statistically indistinguishable from zero.

school graduation and a 3.2 percent reduction in GPA. In comparison, the OLS estimates in column (4) of Table 1 show that stuttering is associated with a $3.3(0.085 / 2.54)$ percent reduction in high school GPA, a $3.5(0.029 / 0.820)$ percent reduction in the probability of high school graduation, and a $7.8(0.046 / 0.589)$ percent reduction in the probability of college attendance. In Appendix Table 2, we explore whether the OLS estimates presented in Table 2 are explained by anxiety or neuroticism in adulthood, as measured at Wave IV of the Add Health. Controlling for these factors reduces the estimated relationship between stuttering and the outcomes under study by roughly a third, suggesting they are not the primary driver of the OLS estimates in Table 2. 


\subsection{Propensity score matching estimates}

The first two columns of Table 4 show the means of the covariates by stuttering status before conducting the matching procedure. We find that stutterers had significantly lower PPVT scores, lower household income during adolescence, less educated parents, and more siblings than their non-stuttering counterparts. They were also more likely to be male, more likely to be Hispanic, were taller, heavier, and more likely to attend public schools without college preparatory courses than non-stutterers. Finally, we find some evidence that stutterers reported a less-close relationship with their fathers than non-stutterers and were more likely to have parents with lower educational expectations. After matching, we find only a handful of significant differences in the means of the observable characteristics (Table 4, columns 3 and 4). ${ }^{13}$

In Table 5, we present the estimated difference in outcomes between stutters and non-stutterers for the unmatched sample and for the matched sample. In the unmatched sample (columns 1, 3, and 5), there is consistent evidence that stuttering is associated with lower academic performance and educational attainment in the pooled sample and by gender. However, after matching on observables, there is little evidence that stuttering is related to these outcomes. For instance, in Panel I, we find that stuttering is associated with a statistically insignificant 0.001 -point increase in GPA, a statistically insignificant 0.005 decrease in the probability of high school graduation, and a statistically insignificant 0.020 decrease in the probability of college attendance. Each of these estimates is much smaller in absolute magnitude than either the unmatched estimates or the OLS estimates presented in Table 2, suggesting that the negative association between stuttering and educational attainment can, in large part, be explained by individual-level

\footnotetext{
${ }^{13}$ Estimates of equation (4) are presented in Appendix Table 3.
} 
characteristics associated with stuttering, particularly the closeness and quality of the parent-child relationship.

\subsection{Estimates controlling for family fixed effects}

In Table 6, we restrict the analysis to biological siblings (including twins) and add family fixed effects as controls. Controlling for family-level unobservables in this fashion substantially reduces the magnitude of the estimated relationship between stuttering and human capital acquisition among siblings. ${ }^{14}$ For instance, when brothers and sisters are pooled, the estimated effect of stuttering on GPA is reduced by 70 percent (0.095/0.136), and the estimated effect on high school graduation is reduced by 77 percent $(0.058 / 0.075)$, leaving each of these estimates statistically indistinguishable from zero (Panel I). Moreover, we find that stuttering is associated with a statistically insignificant 0.013 increase in the probability of college attendance. When we restrict the sample to twins and include family fixed effects, again there is little evidence that stuttering is negatively related to the educational outcomes under study. In general, we see a similar pattern of results when our focus is brothers (Panel II) or on sisters (Panel III).

Taken together, the results in Tables 5 and 6 suggest that failure to control for family-level environment will overstate the effects of stuttering on education. When these factors are addressed, either via propensity score matching or controlling for family fixed effects, we find little evidence that stuttering is negatively related to the outcomes under study.

\footnotetext{
${ }^{14}$ The combined sample contains 289 siblings with discordant stuttering status from 141 families (114 of whom were twins); the male sample is composed of 103 brothers from 51 families ( 46 of whom were twins), and the female sample is composed of 76 sisters from 37 families (38 of whom were twins).
} 


\subsection{Controlling for individual-level heterogeneity}

Finally, in Table 7, we examine the role played by individual-level learning disabilities shown by previous authors to be associated with speech impairments (Blood and Seider 1981; Arndt and Healey 2001; Blood et al. 2003; Blood et al. 2009; AjdacicGross et al. 2010). Specifically, we explore the sensitivity of our OLS estimates to controlling for Attention Deficit Hyperactivity Disorder (ADHD), and the presence of a learning disability such as dyslexia. ${ }^{15}$ Because of missing information on these measures, the sample sizes are reduced by approximately 17 percent as compared to those in Table $2 .^{16}$

Our baseline results are reported in the first column (1) of Table 7. They show that, despite the reduction in sample size, stuttering is associated with a 0.090-point lower

\footnotetext{
${ }^{15}$ At Wave III, respondents were asked "[w]hen you were between the ages of 5 and 12 " you: "fidgeted with your hands or feet or squirmed in your seat," "had difficulty sustaining your attention in tasks or fun activities," "felt restless," "had difficulty organizing tasks and activities," and "had difficulty doing fun things quietly." Possible responses were "never or rarely" $(=0)$, "sometimes" $(=1)$, "often" $(=2)$, or "very often" (=3). Following Fetcher and Wolfe (2008), responses were added to create an ADHD scale ranging from 0 to 54. Our measure of whether the respondent had a learning disability was based on the parent's response (usually the biological mother) to the following question: "Does your child have a specific learning disability, such as difficulties with attention, dyslexia, or some other reading, spelling, writing, or math disability?" If the parent responded in the affirmative, the learning disability measure was coded as 1; otherwise it was coded as 0 . Both our measures of ADHD and learning disability are clearly associated with stuttering (Appendix Table 4). Thirty-six and a half percent of stutterers scored above the $80^{\text {th }}$ percentile on the ADHD scale, while only 19.9 percent of on-sutterers scored above the $80^{\text {th }}$ percentile on the ADHD scale; almost twenty percent of stutterers were reported to have a learning disability, while only 11.4 percent of non-stutterers were reported to have a learning disability.

${ }^{16}$ Although the empirical evidence is not conclusive, there is at least a popular perception that children who stutter are more likely to suffer from low self esteem and depression than children who do not (Miller and Watson 1992; Yovetich et al. 2000; Bray et al. 2003). In a series of regressions, the results of which are available upon request, we explored the relationship between stuttering and human capital acquisition controlling for depression and self-esteem. Controlling for the respondent's score on the Center for Epidemiological Studies Depression Scale (Radloff 1977), stuttering was unrelated to human capital acquisition. However, we could not determine whether depression was a mediator or confounder. Controlling for the respondent's score on the Rosenberg Self-Esteem Scale (Rosenberg 1965) had a small, statistically insignificant, effect on the magnitude of the coefficient of Stutter.
} 
GPA, a (statistically insignificant) 0.017 lower probability of high school graduation, and a 0.033 lower probability of college attendance. However, when we control for ADHD (column 2), the estimated effect of stuttering falls by 64 to 100 percent (depending upon which outcome in on the left-hand side), suggesting that ADHD may explain an important share of the observed correlation between stuttering and schooling. ${ }^{17}$

In column (3), we add a control for whether the respondent's parent reported that their son/daughter suffered from a learning disability at the time of the Wave I survey. Again, we find that controlling for learning disabilities substantially reduces the estimated correlation between stuttering and education, rendering it statistically indistinguishable from zero.

In column (4), we add both of these controls to the right-hand side of the regression. In this specification, we find that the estimated effect of stuttering is uniformly insignificant, much reduced in absolute magnitude, and, in fact, positively related to the probability of graduating high school. ${ }^{18}$ These findings suggest that failing to control for other childhood learning disabilities will result in an overestimate of the effect of stuttering on human capital acquisition.

\footnotetext{
${ }^{17}$ The estimated relationship between stuttering and GPA goes from -0.090 to -0.021 (76.7 percent); the estimated relationship between stuttering and high school graduation goes from -0.017 to 0.0003 ; and the estimated relationship between stuttering and college attendance goes from -0.033 to -0.012 (63.6 percent).

${ }^{18}$ An alternative approach to controlling for unmeasured individual heterogeneity would be to use an instrumental variables (IV) strategy. This approach would require indentifying a variable correlated with stuttering but uncorrelated with the unmeasured determinants of human capital acquisition. Because stuttering has been found to be inheritable (Felsenfeld and Plomin1997; Felsenfeld et al. 2000; Ooki S. 2005; Dworzynski et al. 2007; Kang et al. 2010), we experimented with using an indicator for whether the respondent's biological sibling or cousin had a problem with stuttering as an instrument. There was a strong association between having a biological sibling or cousin who stuttered and the probability that the respondent stuttered. However, IV estimates of the effect stuttering on human capital acquisition were implausibly large in magnitude and too imprecisely estimated to make useful inferences.
} 


\section{CONCLUSION}

Although previous studies have shown that children with speech impairments score lower on tests of reading and math (Catts 1993; Walker et al. 1994; Stothard et al. 1998; Catts et al. 2002; Knox 2002; Nathan et al. 2004; Catts et al. 2008; Harrison et al. 2009; Eide and Showalter 2010; Law et al. 2010) and go on to receive fewer years of education than their counterparts without speech impairments (Snowling et al. 2001; Johnson et al. 2010), their results could easily have been driven by unobservables at the individual, family, school, or neighborhood level. Using data drawn from the National Longitudinal Study of Adolescent Health (Add Health), we explore the relationship between stuttering, a common speech impairment, and three outcomes: high school grade point average, the probability of high school graduation, and the probability of college attendance. Consistent with the results of previous studies (Catts 1993; Walker et al. 1994; Stothard et al. 1998; Snowling et al. 2001; Catts et al. 2002; Knox 2002; Nathan et al. 2004; Catts et al. 2008; Harrison et al. 2009; Eide and Showalter 2010; Law et al. 2010; Johnson et al. 2010), baseline OLS estimates produce evidence that stuttering is negatively related to all three of these outcomes. However, propensity score matching and family fixed effects estimates produce small, often statistically insignificant estimates. Likewise, controlling for whether the respondent has ADHD or some other learning disability results in small, statistically insignificant estimates of the effect of stuttering on our outcomes.

Research by Currie and Stabile (2006), Kaestner and Grossman (2009), Fletcher (2010), Rees and Sabia (2011), and Sabia and Rees (forthcoming) provides evidence that chronic childhood health conditions such as ADHD, obesity, and migraine headache can 
negatively impact the acquisition of human capital. Our results are consistent with the hypothesis that stuttering typically does not interfere with the acquisition of human capital to the same extent as do these other chronic childhood health conditions. They are also consistent with the hypothesis that parents devote more resources to a child who stutters. In fact, Fletcher and Wolfe (2008, p. 799) speculate that the reason their withinfamily estimates of the relationship between ADHD and educational attainment are so much smaller than their cross-sectional estimates is that "parents are more able to compensate children with ADHD, which could lead to smaller within-sibling differences in educational outcomes...”

Although, due to data limitations, we were not able to distinguish between occasional and severe stuttering, our findings underscore the importance of family and individual heterogeneity. Future researchers interested in documenting the relationship between stuttering and a range of social and educational outcomes would be well advised to consider these potentially important sources of bias. Because the impact of stuttering on human capital acquisition may be spurious, it is tempting to conclude that stuttering does not merit the same attention from educators and health care professionals. However, stuttering clearly imposes other costs through interfering with communication and social interactions. Moreover, at least some portion of these costs may be quantifiable. One study found that 20 percent of stutterers reported having been turned down for a job or promotion because of their impairment (Klein and Hood 2004), and stutterers who underwent a speech-fluency treatment program showed improved job promotion (Craig and Calver 1991). In future work, we plan to use the Add Health data to explore the effects of stuttering on labor force participation, occupational choice, 
productivity and earnings. To our knowledge, no previous study has used nationally

representative data to examine the effects of stuttering in the workplace.

\section{REFERENCES}

Ajdacic-Gross, Vladeta, Stefan Vetter, Mario Müller, Wolfram Kawohl, Franz Frey, Gianpiero Lupi, Anja Blechschmidt, Claudia Born, Beatrix Latal, and Wulf Rössler. 2010. "Risk Factors for Stuttering: A Secondary Analysis of a Large Data Base." European Archives of Psychiatry and Clinical Neuroscience, Vol. 260, No. 4, p. 279.

Arndt, Jennifer, and Charles E. Healey. 2001. "Concomitant Disorders in School-Age Children who Stutter." Language, Speech, and Hearing Services in Schools, Vol. 32, No. 2, pp. 68-78.

Bashir, Anthony S., and Annebelle Scavuzzo. 1992. "Children with Language Disorders: Natural History and Academic Success." Journal of Learning Disabilities, Vol. 25, No. 1, pp. 53-65.

Blood, Gordon W. and Ingrid M. Blood. 2004. "Bullying in Adolescents who Stutter: Communicative Competence and Self-Esteem." Contemporary Issues in Communication Science and Disorders, Vol. 31, pp. 69-79.

Blood, Gordon W. and Ingrid M. Blood. 2007. "Preliminary Study of Self-Reported Experience of Physical Aggression and Bullying of Boys who Stutter: Relation to Increased Anxiety." Perceptual and Motor Skills, Vol. 104, No. 3, pp. 1060-1066.

Blood, Gordon W., and Seider, Robin. 1981. "The Concomitant Problems of Young Stutterers." Journal of Speech and Hearing Research, Vol. 46, No. 1, pp. 31-33.

Blood, Gordon W., Victor J. Ridenour, Jr., Constance Dean Qualls, and Carol Scheffner Hammer. 2003. "Co-occurring Disorders in Children who Stutter." Journal of Communication Disorders, Vol. 36, No. 6, pp. 427-448.

Blood Gordon W., Ingrid M. Blood, Kristy Maloney, Crystal Meyer, and Constance Dean Qualls. 2007. "Anxiety Levels in Adolescents who Stutter." Journal of Communication Disorders, Vol. 40, No. 6, pp. 452-469.

Blood, Gordon W., Ingrid Blood, Jennifer Kreiger, Shelah O'Connor, and Constance Dean Qualls. 2009. "Double Jeopardy for Children Who Stutter: Race and Coexisting Disorders." Communication Disorders Quarterly, Vol. 30, No. 3, pp. 131-141. 
Bray, Melissa A. Thomas J. Kehle, Kimberly A. Lawless, and Lea A. Theodore. 2003. "The Relationship of Self-Efficacy and Depression to Stuttering." American Journal of Speech-Language Pathology, Vol.12, pp. 425-431.

Catts, Hugh W. 1993. "The Relationship between Speech-Language Impairments and Reading Disabilities." Journal of Speech and Hearing Research Vol. 36, No. 5, pp. 948958.

Catts, Hugh W., Marc E. Fey, and Xuyang Zhang. 2001. "Estimating the Risk of Future Reading Difficulties in Kindergarten Children: A Research-Based Model and its Clinical Implementation." Language, Speech and Hearing Services in Schools, Vol. 32, No. 1, pp. $38-50$

Catts, Hugh. W., Mindy Sittner Bridges, Todd D. Little, and J. Bruce Tomblin 2008. "Reading Achievement Growth in Children with Language Impairments." Journal of Speech, Language, and Hearing Research, Vol. 51, No. 6, pp. 1569-1579.

Catts, Hugh W., Marc E. Bruce J. Tomblin, and Xuyang Zhang. 2002. "A Longitudinal Investigation of Reading Outcomes in Children with Language Impairments." Journal of Speech, Language, and Hearing Research, Vol. 45, No. 6, p. 1142-1157.

Craig, Ashley and P. Calver. 1991. "Following Up on Treated Stutterers: Studies of Perceptions of Fluency and Job Status." Journal of Speech and Hearing Research, Vol. 34, pp. 279-284.

Craig, Ashley, Karen Hancock, Yvonne Tran, Magali Craig, and K. Peters. 2002. "Epidemiology of Stuttering in the Communication across the Entire Life Span." Journal of Speech Language Hearing Research, Vol. 45, pp. 1097-1105.

Craig, Ashley, Karen Hancock, Yvonne Tran, and Magali Craig. 2003. "Anxiety Levels in People who Stutter. A Randomised Population Study." Journal of Speech, Language and Hearing Research, Vol. 46, No. 5, pp.1197-1206.

Craig, Ashley and Yvonne Tran. 2006. "Fear of Speaking: Chronic Anxiety and Stammering." Advances in Psychiatric Treatment, Vol. 12, No. 1, pp. 63-68.

Craig, Ashley and Yvonne Tran. 2005. "The Epidemiology of Stuttering: The Need for reliable estimates of Prevalence and Anxiety Levels over the Lifespan." Advances in Speech-Language Pathology, Vol. 7, No. 1, pp. $41-46$.

Currie, Janet and Mark Stabile. 2006. "Child Mental Health and Human Capital Accumulation: The Case of ADHD." Journal of Health Economics, Vol. 25, No. 6, pp. 1094-1118. 
Davis, Steven, Peter Howell, and Frances Cooke. 2002. "Sociodynamic Relationships between Children who Stutter and their Non-stuttering Classmates." Journal of Child Psychology and Psychiatry, Vol. 43, No. 7, pp. 939-947.

Dorsey, Michelle and Kim R. Guenther. 2000. "Attitudes of Professors and Students toward College Students Who Stutter." Journal of Fluency Disorders, Vol. 25, No. 1, pp. $77-83$.

Dworzynski, Katharina, Anna Remington, Frühling Rijsdijk, Peter Howell, and Robert Plomin. 2007. "Genetic Etiology in Cases of Recovered and Persistent Stuttering in an Unselected, Longitudinal Sample of Young Twins." American Journal of SpeechLanguage Pathology, Vol. 16, No. 2, pp.169-178.

Eide, Eric, Mark H. Showalter, and Dan D. Goldhaber.2010. "The Relation between Children's Health and Academic Achievement." Children and Youth Services Review, Vol. 32, No. 2, pp. 231-238.

Felsenfeld, Susan, and Robert Plomin. 1997. "Epidemiological and Offspring Analyses of Developmental Speech Disorders using Data from the Colorado Adoption Project." Journal of Speech, Language, and Hearing Research, Vol. 40, No. 4, pp. 778-91.

Felsenfeld, S., K.M. Kirk, G. Zhu, D.J. Statham, M.C. Neale, N.G. Martin. 2000. “A Study of the Genetic and Environmental Etiology of Stuttering in a Selected Twin Sample." Behavior and Genetics, Vol. 30, No. 5, pp. 359-366.

Fletcher, Jason. 2010. "Adolescent Depression and Educational Attainment: Evidence from Sibling Fixed Effects.” Health Economics, Vol. 19, No. 7, pp. 855-871.

Fletcher, Jason, and Barbara Wolfe. 2008. "Child Mental Health and Human Capital Accumulation: The Case of ADHD Revisited." Journal of Health Economics, Vol. 27, No. 3, pp. 794-800.

Gordon, Neil. 2002. "Stuttering: Incidence and Causes." Developmental Medicine and Child Neurology, Vol. 44, No. 4, pp. 278-282.

Hancock, Karen, Ashley Craig, Chris McCready, Annette McCaul, Deborah Costello, Karen Campbell, and Gillian Gilmore. 1998. "Two to Six Year Controlled Trial Stuttering Outcomes for Children and Adolescents." Journal of Speech, Language and Hearing Research, Vol. 41, pp. 1242-1252.

Harris, Kathleen M., Francesca Florey, Joyce Tabor, Peter S. Bearman, Jo Jones, and J. Richard Udry. The National Longitudinal Study of Adolescent Health: research design. Available at http://www.cpc.unc.edu/projects/addhealth/design. Accessed April 16, 2007.

Harrison, Linda J., Sharynne McLeod, Donna Berthelsen, and Sue Walker. 2009.

"Literacy, Numeracy, and Learning in School-Aged Children Identified as having Speech 
and Language Impairment in Early Childhood." International Journal of Speech Language Pathology, Vol. 11, No. 5, pp. 392-403.

Johnson, Carla J., Joseph H. Beitchman, and E. B. Brownlie. 2010. “Twenty-Year Follow-Up of Children with and without Speech-Language Impairments: Family, Educational, Occupational, and Quality of Life Outcomes." American Journal of SpeechLanguage Pathology Vol.19, No. 1, pp. 51-65.

Kaestner, Robert and Michael Grossman. 2009. "Effects of Weight on Children's Educational Achievement." Economics of Education Review, Vol. 28, No. 6, pp. 651661.

Kang, Changsoo, Sheikh Riazuddin, Jennifer Mundorff, Donna Krasnewich, Penelope Friedman, James C. Mullikin., and Dennis Drayna. 2010. "Mutations in the Lysosomal Enzyme-Targeting Pathway and Persistent Stuttering." The New England Journal of Medicine, Vol. 362, No. 8, pp. 677-685.

Klein, Joseph F. and Stephen B. Hood. 2004. "The Impact of Stuttering on Employment Opportunities and Job Performance.” Journal of Fluency Disorders. Vol. 29, No. 4, pp. 255-273.

Knox, Emma. 2002. "Educational Attainments of Children with Specific Language Impairment at Age 6." Child Language Teaching and Therapy 2002, Vol. 18, No. 2, pp. 103-124.

Lass, Norman J., Dennis M. Ruscello, John F. Schmitt, Mary D. Pannbacker, Mary B. Orlando, Kathy A. Dean, Julie C. Ruziska, and Karen H. Bradshaw. 1992. "Teachers' Perceptions of Stutters." Language, Speech, and Hearing Services in Schools Vol. 23, pp. $78-81$.

Law, James, Robert Rush, Ingrid Schoon, and Samantha Parsons. 2010. "Modeling Developmental Language Difficulties from School Entry Into Adulthood: Literacy, Mental Health, and Employment Outcomes." Journal of Speech, Language, and Hearing Research, Vol. 52, No 6, pp. 1401-1416.

Langevin, Marilyn, and Paul Hagler. 2004. "Development of a Scale to Measure Peer Attitude toward Children who Stutter." In Evidence-Based Treatment of Stuttering. Empirical Issues and Clinical Implications (ed. A. K. Bothe), pp. 139-171. Mahwah, NJ: Lawrence Erlbaum Associates.

Levine, David I., and Gary Painter. 2003. "The Costs of Teenage Out-of Wedlock Childbearing: Analysis with a Within-School Propensity Score Matching Estimator." Review of Economics and Statistics, Vol. 85, No. 4, pp. 884-900.

Mansson, Hans. 2000. "Childhood Stuttering: Incidence and Development." Journal of Fluency Disorders, Vol. 25, No. 1, pp. 47-57. 
Miller, Susan, and Ben C. Watson. 1992. "The Relationship between Communication Attitude, Anxiety, and Depression in Stutterers and Nonstutterers." Journal of Speech and Hearing Research, Vol. 35, No.4, pp. 789-798.

Nathan, Liz, Joy Stackhouse, Nata Goulandris, and Margaret J. Snowling. 2004. "Educational Consequences of Developmental Speech Disorder: Key Stage 1 National Curriculum Assessment Results in English and Mathematics." British Journal of Educational Psychology, Vol. 74, No. 2, pp. 173-186.

Nippold, Marilyn A., and Mishelle Rudzinski. 1995. "Parents' Speech and Children's Stuttering: A Critique of the Literature." Journal of Speech and Hearing Research, Vol. 38, No. 5, pp. 978-989.

Norman J. Lass, Dennis M. Ruscello, Mary Pannbacker, John F. Schmitt, Angela Marsh Kiser, Ashraf M. Mussa, and Patricia Lockhart. 1994. "School Administrators' Perceptions of People Who Stutter." Language, Speech, and Hearing Services in Schools, Vol. 25, No. 2, pp. 90-93.

Ooki, Syuichi. 2005. "Genetic and Environmental Influences on Stuttering and Tics in Japanese Twin Children.” Twin Research and Human Genetics, Vol. 8, No. 1, pp. 69-75.

Radloff, LS. 1977. "The CES-D Scale: A self-report depression scale for research in the general population," Applied Psychological Measurement, Vol. 1, No. 3, pp. 385-401.

Ratcliff-Baird, Brenda. 2001. "ADHD and Stuttering: Similar EEG Profiles Suggest Neurotherapy as an Adjunct to Traditional Speech Therapies." Journal of Neurotherapy, Vol. 5, No. 4, pp. 5-22.

Reilly, Sheena, Mark Onslow, Ann Packman, Melissa Wake, Edith L. Bavin, Margot Prior, Patricia Eadie, Eileen Cini, Catherine Bolzonello, and Obioha C. Ukoumunne. 2009. "Predicting Stuttering Onset by the Age of 3 Years: A Prospective, Community Cohort Study.” Pediatrics, Vol. 123, No. 1, pp. 270-277.

Rees, Daniel I. and Joseph J. Sabia. 2011. "The Effect of Migraine Headache on Educational Attainment." The Journal of Human Resources, Vol. 46, No. 2, pp. 317-332.

Sabia, Joseph J. 2007. "Early Adolescent Sex and Diminished Academic Performance: Spillovers or Selection?” Southern Economic Journal, Vol. 74, No. 1, pp. 239-268.

Sabia, Joseph J.. Daniel I. Rees. Forthcoming. "Individual Heterogeneity and Reverse Causality in the Relationship between Migraine Headache and Educational Attainment." Economics of Education Review.

Rosenbaum, Paul R., and Donald B. Rubin. 1983. "The Central Role of the Propensity 
Score in Observational Studies for Causal Effects.” Biometrika, Vol. 70, No. 1, pp. 4155 .

Ruscello, Dennis M., Norman J. Lass, John F. Schmitt, and Mary D. Pannbacker. 1994. "Special educators' Perceptions of Stutterers." Journal of Fluency Disorders, Vol. 19, No. 2, pp. 125-132.

Snowling, Margaret J., John W. Adams, D. V. M. Bishop, and Susan E. Stothard. 2001. "Educational Attainments of School Leavers with a Preschool History of SpeechLanguage Impairments." International Journal of Language Communication Disorders, Vol. 36, No, 2, pp. 173-183.

Stothard, Susan E., Margaret J. Snowling, D.V.M Bishop, Barry B Chipchase, and Carole A.Kaplan. 1998. "Language-Impaired Preschoolers: A Follow-Up into Adolescence." Journal of Speech, Language and Hearing Research, Vol. 41 No. 2, pp. 407-419.

Viswanath, Nagalapura, Hee Suk Lee, and Ranajit Chakraborty. 2004. "Evidence for a Major Gene Influence on Persistent Developmental Stuttering." Human Biology, Vol. 76, No. 3, pp. 401-412.

Yeakle, Mary Kaye and Eugene B. Cooper. 1986. “Teacher Perceptions of Stuttering.” Journal of Fluency Disorders, Vol. 11, No. 4, pp. 345-359.

Young, Arlene R., Joseph H. Beitchman, Carla Johnson, Lori Douglas, Leslie Atkinson, Michael Escobar, and Beth Wilson. 2002. "Young Adult Academic Outcomes in a Longitudinal Sample of Early Identified Language Impaired and Control Children." Journal of Child Psychology and Psychiatry, Vol. 43, No. 5, pp. 635-645.

Yovetich, WM.S., Alan W. Leschied, and Jason Flicht. 2000. "Self-Esteem of SchoolAge Children who Stutter.” Journal of Fluency Disorders, Vol. 25, No. 2, pp. 143-153.

Walker, Dale, Charles Greenwood, Betty Hart, and Judith Carta. 1994. "Prediction of School Outcomes Based on Early Language Production and Socioeconomic Factors." Child Development, Vol. 65, No. 2, pp. 606-621. 
Table 1. Means of Key Variables, by Gender

\begin{tabular}{|c|c|c|c|}
\hline & All & Males & Females \\
\hline \multirow[t]{3}{*}{ High School GPA } & 2.54 & 2.39 & 2.69 \\
\hline & $(0.837)$ & $(0.841)$ & $(0.808)$ \\
\hline & {$[10,834]$} & {$[5,175]$} & {$[5,659]$} \\
\hline \multirow[t]{3}{*}{ High School Diploma } & 0.820 & 0.798 & 0.841 \\
\hline & $(0.384)$ & $(0.402)$ & $(0.366)$ \\
\hline & {$[13,549]$} & {$[6,458]$} & {$[7,091]$} \\
\hline \multirow[t]{3}{*}{ College Attendance } & 0.589 & 0.549 & 0.625 \\
\hline & $(0.492)$ & $(0.498)$ & $(0.484)$ \\
\hline & {$[13,549]$} & {$[6,458]$} & {$[7,091]$} \\
\hline \multirow[t]{3}{*}{ Stutter } & 0.070 & 0.086 & 0.056 \\
\hline & $(0.256)$ & $(0.280)$ & $(0.230)$ \\
\hline & {$[13,549]$} & {$[6,458]$} & {$[7,091]$} \\
\hline \multirow[t]{3}{*}{$\mathrm{GPA} \geq 3.5$} & 0.031 & 0.050 & 0.021 \\
\hline & (0.174) & $(0.218)$ & (0.145) \\
\hline & {$[1,481]$} & [500] & [981] \\
\hline \multirow[t]{3}{*}{ GPA $<3.5$} & 0.076 & 0.091 & 0.062 \\
\hline & $(0.266)$ & $(0.288)$ & $(0.240)$ \\
\hline & {$[9,353]$} & {$[4,675]$} & {$[4,678]$} \\
\hline \multirow[t]{3}{*}{ HS Grad } & 0.065 & 0.079 & 0.053 \\
\hline & $(0.247)$ & (0.269) & (0.224) \\
\hline & {$[11,112]$} & {$[5,152]$} & {$[5,960]$} \\
\hline \multirow[t]{3}{*}{ Dropout } & 0.095 & 0.114 & 0.073 \\
\hline & (0.293) & $(0.318)$ & (0.259) \\
\hline & {$[2,437]$} & {$[1,306]$} & {$[1,131]$} \\
\hline \multirow[t]{3}{*}{ College } & 0.056 & 0.071 & 0.045 \\
\hline & $(0.231)$ & $(0.256)$ & (0.208) \\
\hline & {$[7,976]$} & {$[3,543]$} & {$[4,433]$} \\
\hline \multirow[t]{3}{*}{ No College } & 0.090 & 0.105 & 0.075 \\
\hline & $(0.287)$ & $(0.306)$ & $(0.263)$ \\
\hline & {$[5,573]$} & {$[2,915]$} & {$[2,658]$} \\
\hline
\end{tabular}

Notes: All means were obtained using unweighted data drawn from Wave III of the National Longitudinal Study of Adolescent Health. Standard deviations are in parentheses and sample sizes are in brackets. 


\begin{tabular}{|c|c|c|c|c|}
\hline & (1) & $(2)$ & (3) & $(4)$ \\
\hline & \multicolumn{4}{|c|}{ Panel I: Grade Point Average } \\
\hline Stutter & $\begin{array}{c}-0.240 * * * \\
(0.032)\end{array}$ & $\begin{array}{c}-0.121 * * * \\
(0.028)\end{array}$ & $\begin{array}{c}-0.087^{* * *} \\
(0.028)\end{array}$ & $\begin{array}{c}-0.085^{* * *} \\
(0.027)\end{array}$ \\
\hline Controls for Individual and & No & Yes & Yes & Yes \\
\hline \multicolumn{5}{|l|}{ Family Background Characteristics? } \\
\hline \multicolumn{5}{|l|}{ Control for PPVT Score? } \\
\hline \multicolumn{4}{|l|}{ Community Characteristics? } & Yes \\
\hline \multirow[t]{2}{*}{$\mathrm{N}$} & 10,834 & 10,834 & 10,834 & 10,834 \\
\hline & \multicolumn{4}{|c|}{ Panel II: High School Graduation } \\
\hline Stutter & $\begin{array}{c}-0.067^{* * *} \\
(0.015)\end{array}$ & $\begin{array}{c}-0.038 * * * \\
(0.014)\end{array}$ & $\begin{array}{c}-0.030 * * \\
(0.013)\end{array}$ & $\begin{array}{c}-0.029 * * \\
(0.013)\end{array}$ \\
\hline \multicolumn{5}{|l|}{ Controls for Individual and } \\
\hline Family Background Characteristics? & No & Yes & Yes & Yes \\
\hline Control for PPVT Score? & No & No & Yes & Yes \\
\hline \multicolumn{5}{|l|}{ Controls for School and } \\
\hline Community Characteristics? & No & No & No & Yes \\
\hline \multirow[t]{2}{*}{$\mathrm{N}$} & 13,549 & 13,549 & 13,549 & 13,549 \\
\hline & \multicolumn{4}{|c|}{ Panel III: College Attendance } \\
\hline Stutter & $\begin{array}{c}-0.126 * * * \\
(0.017)\end{array}$ & $\begin{array}{c}-0.068 * * * \\
(0.015)\end{array}$ & $\begin{array}{c}-0.051 * * * \\
(0.014)\end{array}$ & $\begin{array}{c}-0.046 * * * \\
(0.014)\end{array}$ \\
\hline \multicolumn{5}{|l|}{ Controls for Individual and } \\
\hline Family Background Characteristics? & No & Yes & Yes & Yes \\
\hline Control for PPVT Score? & No & No & Yes & Yes \\
\hline \multicolumn{5}{|l|}{ Controls for School and } \\
\hline Community Characteristics? & No & No & No & Yes \\
\hline $\mathrm{N}$ & 13,549 & 13,549 & 13,549 & 13,549 \\
\hline
\end{tabular}

$* * *$ Significant at $1 \%$ level $* *$ Significant at $5 \%$ level * Significant at $10 \%$ level Notes: All estimates were obtained using unweighted data drawn from Waves I and III of the National Longitudinal Study of Adolescent Health. Standard errors corrected for clustering on the school are in parentheses. 


\section{Table 3. School Fixed Effects Estimates of the Effect of Stuttering on Education}

\begin{tabular}{|c|c|c|c|c|c|c|}
\hline & \multicolumn{2}{|c|}{ Grade Point Average } & \multicolumn{2}{|c|}{ High School Graduation } & \multicolumn{2}{|c|}{ College Attendance } \\
\hline & OLS & SFE & OLS & SFE & OLS & SFE \\
\hline & (1) & (2) & (3) & (4) & (5) & (6) \\
\hline & & & & & & \\
\hline \multirow[t]{2}{*}{ Stutter } & $\begin{array}{c}-0.085 * * * \\
(0.027) \\
{[10,834]}\end{array}$ & $\begin{array}{c}-0.068^{* *} \\
(0.027) \\
{[10,834]}\end{array}$ & $\begin{array}{c}-0.029 * * \\
(0.013) \\
{[13,547]}\end{array}$ & $\begin{array}{c}-0.021 \\
(0.013) \\
{[13,547]}\end{array}$ & $\begin{array}{c}-0.046 * * * \\
(0.014) \\
{[13,547]}\end{array}$ & $\begin{array}{c}-0.042 * * * \\
(0.014) \\
{[13,547]}\end{array}$ \\
\hline & \multicolumn{6}{|c|}{ Panel II: Males } \\
\hline \multirow[t]{2}{*}{ Stutter } & $\begin{array}{c}-0.067 * * \\
(0.032) \\
{[5,175]}\end{array}$ & $\begin{array}{l}-0.062 * \\
(0.032) \\
{[5,175]}\end{array}$ & $\begin{array}{c}-0.036 * * \\
(0.017) \\
{[6,457]}\end{array}$ & $\begin{array}{c}-0.030 * \\
(0.017) \\
{[6,457]}\end{array}$ & $\begin{array}{c}-0.043 * * \\
(0.019) \\
{[6,457]}\end{array}$ & $\begin{array}{c}-0.040 * * \\
(0.019) \\
{[6,457]}\end{array}$ \\
\hline & \multicolumn{6}{|c|}{ Panel III: Females } \\
\hline Stutter & $\begin{array}{c}-0.114^{* * *} \\
(0.040) \\
{[5,659]}\end{array}$ & $\begin{array}{c}-0.086 * * \\
(0.039) \\
{[5,659]}\end{array}$ & $\begin{array}{l}-0.018 \\
(0.019) \\
{[7,090]}\end{array}$ & $\begin{array}{l}-0.008 \\
(0.019) \\
{[7,090]}\end{array}$ & $\begin{array}{c}-0.049 * * \\
(0.022) \\
{[7,090]}\end{array}$ & $\begin{array}{c}-0.041^{*} \\
(0.021) \\
{[7,090]}\end{array}$ \\
\hline
\end{tabular}

\footnotetext{
*** Significant at $1 \%$ level $* *$ Significant at $5 \%$ level * Significant at $10 \%$ level
} Notes: All estimates were obtained using unweighted data drawn from Waves I and III of the National Longitudinal Study of Adolescent Health. Standard errors corrected for clustering on the school are in parentheses. 
Table 4. Means of Key Covariates Before and After Nearest Neighbor Matching of Stutterers and Non-Stutterers

\begin{tabular}{|c|c|c|c|c|}
\hline & \multicolumn{2}{|c|}{ Unmatched Sample } & \multicolumn{2}{|c|}{ Matched Sample } \\
\hline & Stutter & No Stutter & Stutter & No Stutter \\
\hline \multirow[t]{2}{*}{ Peabody Picture-Vocabulary Test Score } & $95.6^{* * *}$ & 99.5 & 96.8 & 95.7 \\
\hline & \multicolumn{2}{|c|}{$p=0.00$} & \multicolumn{2}{|c|}{$p=0.43$} \\
\hline \multirow[t]{2}{*}{ Parents Never Married } & 0.053 & 0.054 & 0.058 & 0.065 \\
\hline & \multicolumn{2}{|c|}{$p=0.94$} & \multicolumn{2}{|c|}{$p=0.75$} \\
\hline \multirow[t]{2}{*}{ Parents Divorced } & 0.148 & 0.140 & 0.150 & 0.140 \\
\hline & \multicolumn{2}{|c|}{$p=0.51$} & \multicolumn{2}{|c|}{$p=0.82$} \\
\hline \multirow[t]{2}{*}{ Parents Separated } & 0.052 & 0.049 & 0.052 & 0.019 \\
\hline & \multicolumn{2}{|c|}{$p=0.65$} & \multicolumn{2}{|c|}{$p=0.13$} \\
\hline \multirow[t]{2}{*}{ Parent Widowed } & 0.042 & 0.037 & 0.040 & 0.065 \\
\hline & \multicolumn{2}{|c|}{$p=0.39$} & \multicolumn{2}{|c|}{$p=0.23$} \\
\hline \multirow[t]{2}{*}{ Age at Wave III } & 22.3 & 22.3 & 22.3 & 22.6 \\
\hline & \multicolumn{2}{|c|}{$p=0.94$} & \multicolumn{2}{|c|}{$p=0.13$} \\
\hline \multirow[t]{2}{*}{ Natural Log of Household Income } & $10.3^{* * *}$ & 10.5 & 10.3 & 10.2 \\
\hline & \multicolumn{2}{|c|}{$p=0.00$} & \multicolumn{2}{|c|}{$p=0.15$} \\
\hline \multirow[t]{2}{*}{ Parent Failed to Complete High School } & $0.140 * *$ & 0.112 & 0.129 & 0.168 \\
\hline & \multicolumn{2}{|c|}{$p=0.02$} & \multicolumn{2}{|c|}{$p=0.27$} \\
\hline \multirow[t]{2}{*}{ Parent Completed High School Only } & $0.321 * *$ & 0.285 & 0.319 & 0.290 \\
\hline & \multicolumn{2}{|c|}{$p=0.03$} & \multicolumn{2}{|c|}{$p=0.55$} \\
\hline \multirow[t]{2}{*}{ Parent Attended Trade School } & 0.087 & 0.095 & 0.087 & 0.084 \\
\hline & \multicolumn{2}{|c|}{$p=0.46$} & \multicolumn{2}{|c|}{$p=0.93$} \\
\hline Parent Completed Some College & 0.186 & 0.197 & 0.192 & 0.150 \\
\hline & & 0.44 & & 0.28 \\
\hline Parent has College Degree & $0.114 * * *$ & 0.147 & 0.124 & 0.112 \\
\hline & & 0.01 & & 0.76 \\
\hline Parent has Post-College Education & $0.062^{* * *}$ & 0.097 & 0.069 & 0.056 \\
\hline & & 0.00 & & 0.62 \\
\hline Female & $0.418 * * *$ & 0.531 & 0.442 & 0.370 \\
\hline & $p=$ & 0.00 & & 0.00 \\
\hline
\end{tabular}




\begin{tabular}{|c|c|c|c|c|}
\hline & \multicolumn{2}{|c|}{ Unmatched Sample } & \multicolumn{2}{|c|}{ Matched Sample } \\
\hline & Stutter & No Stutter & Stutter & No Stutter \\
\hline \multirow[t]{2}{*}{ Black } & 0.232 & 0.22 & 0.228 & 0.218 \\
\hline & \multicolumn{2}{|c|}{$p=0.40$} & \multicolumn{2}{|c|}{$p=0.81$} \\
\hline \multirow[t]{2}{*}{ Asian } & 0.081 & 0.076 & 0.086 & 0.076 \\
\hline & \multicolumn{2}{|c|}{$p=0.63$} & \multicolumn{2}{|c|}{$p=0.63$} \\
\hline \multirow[t]{2}{*}{ Native American } & $0.027^{* * *}$ & 0.015 & 0.023 & 0.033 \\
\hline & \multicolumn{2}{|c|}{$p=0.00$} & \multicolumn{2}{|c|}{$p=0.45$} \\
\hline \multirow[t]{2}{*}{ Hispanic/Other } & $0.212 * * *$ & 0.172 & 0.203 & 0.218 \\
\hline & \multicolumn{2}{|c|}{$p=0.00$} & \multicolumn{2}{|c|}{$p=0.71$} \\
\hline \multirow[t]{2}{*}{ Catholic } & 0.273 & 0.262 & 0.279 & 0.292 \\
\hline & \multicolumn{2}{|c|}{$p=0.45$} & \multicolumn{2}{|c|}{0.78} \\
\hline \multirow[t]{2}{*}{ Baptist or Methodist } & 0.363 & 0.382 & 0.367 & 0.372 \\
\hline & \multicolumn{2}{|c|}{$p=0.26$} & \multicolumn{2}{|c|}{$p=0.92$} \\
\hline \multirow[t]{2}{*}{ Other Christian } & 0.184 & 0.192 & 0.184 & 0.177 \\
\hline & \multicolumn{2}{|c|}{$p=0.55$} & \multicolumn{2}{|c|}{$p=0.87$} \\
\hline \multirow[t]{2}{*}{ Non-Christian Religious Affiliation } & 0.036 & 0.045 & 0.036 & 0.44 \\
\hline & \multicolumn{2}{|c|}{$p=0.20$} & \multicolumn{2}{|c|}{$p=0.66$} \\
\hline \multirow[t]{2}{*}{ Height (in) } & $67.0^{* * *}$ & 66.5 & 6639 & 67.2 \\
\hline & \multicolumn{2}{|c|}{$p=0.00$} & \multicolumn{2}{|c|}{$p=0.42$} \\
\hline \multirow[t]{2}{*}{ Weight (lbs) } & $147.7^{* * *}$ & 143.9 & 147.4 & 147.9 \\
\hline & \multicolumn{2}{|c|}{$p=0.00$} & \multicolumn{2}{|c|}{$p=0.90$} \\
\hline Whether Has Older Sibling & 0.530 & 0.506 & 0.522 & 0.534 \\
\hline & & .16 & & 0.82 \\
\hline Number of Siblings & $1.76 * *$ & 1.64 & 1.71 & 1.7 \\
\hline & & .02 & & 0.99 \\
\hline Suburban & 0.551 & 0.544 & 0.562 & 0.559 \\
\hline & & .68 & & 0.93 \\
\hline Rural & 0.182 & 0.176 & 0.180 & 0.237 \\
\hline & $p=$ & .70 & & 0.14 \\
\hline
\end{tabular}




\begin{tabular}{|c|c|c|c|c|}
\hline & \multicolumn{2}{|c|}{ Unmatched Sample } & \multicolumn{2}{|c|}{ Matched Sample } \\
\hline & Stutter & No Stutter & Stutter & No Stutter \\
\hline \multirow[t]{2}{*}{ West } & $0.212^{* * *}$ & 0.256 & 0.215 & 0.220 \\
\hline & \multicolumn{2}{|c|}{$p=0.00$} & \multicolumn{2}{|c|}{$p=0.91$} \\
\hline \multirow[t]{2}{*}{ South } & 0.358 & 0.374 & 0.361 & 0.356 \\
\hline & \multicolumn{2}{|c|}{$p=0.31$} & \multicolumn{2}{|c|}{$p=0.89$} \\
\hline \multirow[t]{2}{*}{ Midwest } & 0.117 & 0.126 & 0.124 & 0.110 \\
\hline & \multicolumn{2}{|c|}{$p=0.38$} & \multicolumn{2}{|c|}{$p=0.67$} \\
\hline \multirow[t]{2}{*}{ Very Unattractive } & 0.010 & 0.010 & 0.008 & 0.025 \\
\hline & \multicolumn{2}{|c|}{$p=0.99$} & \multicolumn{2}{|c|}{$p=0.15$} \\
\hline \multirow[t]{2}{*}{ Unattractive } & $0.061 * *$ & 0.041 & 0.051 & 0.037 \\
\hline & \multicolumn{2}{|c|}{$p=0.01$} & \multicolumn{2}{|c|}{$p=0.56$} \\
\hline \multirow[t]{2}{*}{ Attractive } & $0.308 * * *$ & 0.372 & 0.318 & 0.354 \\
\hline & \multicolumn{2}{|c|}{$p=0.00$} & \multicolumn{2}{|c|}{$p=0.51$} \\
\hline \multirow[t]{2}{*}{ Very Attractive } & 0.120 & 0.132 & 0.123 & 0.110 \\
\hline & \multicolumn{2}{|c|}{$p=0.34$} & \multicolumn{2}{|c|}{$p=0.72$} \\
\hline \multirow[t]{2}{*}{ Average class size } & $26.5^{*}$ & 25.9 & 26.7 & 26.4 \\
\hline & \multicolumn{2}{|c|}{$p=0.09$} & \multicolumn{2}{|c|}{$p=0.72$} \\
\hline \multirow[t]{2}{*}{ Whether attend public school } & $0.947 * * *$ & 0.911 & 0.941 & 0.941 \\
\hline & \multicolumn{2}{|c|}{$p=0.00$} & \multicolumn{2}{|c|}{$p=0.99$} \\
\hline Whether school has college prep & $0.439 * * *$ & 0.488 & 0.458 & 0.466 \\
\hline courses & & 0.00 & & 0.80 \\
\hline \multirow[t]{2}{*}{ Feel close to father-- 4 on 5-pt scale } & $0.028 * * *$ & 0.016 & 0.027 & 0.025 \\
\hline & \multicolumn{2}{|c|}{$p=0.00$} & \multicolumn{2}{|c|}{$p=0.91$} \\
\hline Feel close to father -- 5 on 5-pt scale & $0.136^{*}$ & 0.160 & 0.142 & 0.118 \\
\hline & & 0.05 & & 0.49 \\
\hline Feel close to mother-- 4 on 5-pt scale & 0.190 & 0.210 & 0.195 & 0.134 \\
\hline & & .14 & & 0.12 \\
\hline Feel close to mother -- 5 on 5-pt scale & 0.599 & 0.620 & 0.604 & 0.664 \\
\hline & $p=$ & .19 & & 0.21 \\
\hline
\end{tabular}




\begin{tabular}{|c|c|c|c|c|}
\hline & \multicolumn{2}{|c|}{ Unmatched Sample } & \multicolumn{2}{|c|}{ Matched Sample } \\
\hline & Stutter & No Stutter & Stutter & No Stutter \\
\hline Mother would be disappointed if failed & $0.145^{* *}$ & 0.143 & 0.149 & 0.168 \\
\hline to graduate college -- 4 on 5 -point scale & \multicolumn{2}{|c|}{$p=0.02$} & \multicolumn{2}{|c|}{$p=0.59$} \\
\hline Mother would be disappointed if failed & 0.451 & 0.470 & $0.460 *$ & 0.362 \\
\hline to graduate college -- 5 on 5 -point scale & \multicolumn{2}{|c|}{$p=0.26$} & \multicolumn{2}{|c|}{$p=0.05$} \\
\hline Mother would be disappointed if failed & $0.057^{*}$ & 0.045 & 0.054 & 0.067 \\
\hline to graduate HS -- 4 on 5-point scale & \multicolumn{2}{|c|}{ p 0.09} & \multicolumn{2}{|c|}{$p=0.56$} \\
\hline Mother would be disappointed if failed & $0.773 * * *$ & 0.828 & 0.788 & 0.723 \\
\hline to graduate HS -- 5 on 5-point scale & \multicolumn{2}{|c|}{$p=0.00$} & \multicolumn{2}{|c|}{$p=0.11$} \\
\hline
\end{tabular}

\footnotetext{
$* * *$ Means statistically different at $1 \%$ level

** Means statistically different at $5 \%$ level

* Means statistically different at $10 \%$ level
}

Notes: All means generated from data from Waves I and III of the National Longitudinal Study of Adolescent Health. The matched sample is generated using a nearest neighbor matching procedure where each stutteret was matched to a non-stutterer with a propensity score difference of less than or equal to 0.003 . Treatment observations with a propensity score greater than the maximum or less than the minimum propensity score of the control group were dropped from the analysis, as were treatment observations with a propensity score match in the lowest 4.5 percent of the distribution. Nearest neighbor matching was conducted without replacement. 
Table 5. Propensity Score Matching Estimates of the Effect of Stuttering on Education

\begin{tabular}{|c|c|c|c|c|c|c|}
\hline & \multicolumn{2}{|c|}{ Grade Point Average } & \multicolumn{2}{|c|}{ High School Graduation } & \multicolumn{2}{|c|}{ College Attendance } \\
\hline & Unmatched & PSM & Unmatched & PSM & Unmatched & PSM \\
\hline & (1) & (2) & (3) & (4) & (5) & (6) \\
\hline & & & Pan & & & \\
\hline \multirow[t]{4}{*}{ Stutter } & $-0.236 * * *$ & 0.001 & $-0.067 * * *$ & -0.005 & $-0.126 * * *$ & -0.020 \\
\hline & $(0.031)$ & $(0.031)$ & $(0.013)$ & $(0.015)$ & $(0.016)$ & $(0.018)$ \\
\hline & {$[10,566]$} & {$[1,356]$} & {$[13,333]$} & {$[1,704]$} & {$[13,333]$} & {$[1,704]$} \\
\hline & \multicolumn{6}{|c|}{ Panel II: Males } \\
\hline \multirow[t]{4}{*}{ Stutter } & $-0.168 * * *$ & 0.029 & $-0.076 * * *$ & -0.004 & $-0.111 * * *$ & -0.023 \\
\hline & $(0.041)$ & $(0.044)$ & $(0.018)$ & $(0.021)$ & $(0.022)$ & $(0.024)$ \\
\hline & {$[4,896]$} & {$[792]$} & {$[6,148]$} & [958] & {$[6,148]$} & [958] \\
\hline & \multicolumn{6}{|c|}{ Panel III: Females } \\
\hline \multirow[t]{3}{*}{ Stutter } & $-0.226 * * *$ & -0.042 & $-0.046 * *$ & 0.014 & $-0.120 * * *$ & -0.009 \\
\hline & $(0.048)$ & $(0.050)$ & (0.019) & $(0.023)$ & $(0.025)$ & (0.029) \\
\hline & {$[4,876]$} & {$[538]$} & {$[6,425]$} & {$[688]$} & {$[6,425]$} & [688] \\
\hline
\end{tabular}

\footnotetext{
$* * *$ Significant at $1 \%$ level $* *$ Significant at $5 \%$ level $*$ Significant at $10 \%$ level Notes: All estimates obtained using data from Waves I and III of the National Longitudinal Study of Adolescent Health. The matched sample is generated using a nearest neighbor matching procedure where each rape victim was matched to a non-victim with a predicted propensity score difference of less than or equal to 0.003 . Treatment observations with a propensity score greater than the maximum or less than the minimum propensity score of the control group were dropped from the analysis, as were treatment observations with a propensity score match in the lowest 4.5 percent of the distribution. Nearest neighbor matching was conducted without replacement. Standard errors are in parentheses and sample sizes in brackets.
} 


\section{Table 6. Family Fixed Effects Estimates of the Effect of Stuttering on Education}

\begin{tabular}{|c|c|c|c|c|c|c|c|c|c|}
\hline & \multicolumn{3}{|c|}{ Grade Point Average } & \multicolumn{3}{|c|}{ High School Graduation } & \multicolumn{3}{|c|}{ College Attendance } \\
\hline & \multicolumn{2}{|c|}{ Siblings } & \multirow{2}{*}{$\begin{array}{c}\text { Twins } \\
\text { FFE }\end{array}$} & \multicolumn{2}{|c|}{ Siblings } & \multirow{2}{*}{$\begin{array}{c}\text { Twins } \\
\text { FFE }\end{array}$} & \multicolumn{2}{|c|}{ Siblings } & \multirow{2}{*}{$\begin{array}{c}\text { Twins } \\
\text { FFE }\end{array}$} \\
\hline & OLS & FFE & & OLS & FFE & & OLS & FFE & \\
\hline & $(1)$ & $(2)$ & (3) & $(4)$ & (5) & $(6)$ & (7) & $(8)$ & (9) \\
\hline & & & & & anel I: A & & & & \\
\hline \multirow[t]{4}{*}{ Stutter } & $-0.136^{*}$ & -0.041 & 0.002 & $-0.075^{* *}$ & -0.017 & -0.001 & -0.018 & 0.013 & 0.111 \\
\hline & $(0.072)$ & $(0.072)$ & (0.095) & $(0.035)$ & $(0.034)$ & $(0.049)$ & (0.037) & $(0.043)$ & $(0.068)$ \\
\hline & {$[1,643]$} & {$[1,643]$} & {$[666]$} & {$[2,286]$} & {$[2,286]$} & {$[944]$} & {$[2,286]$} & {$[2,286]$} & [844] \\
\hline & \multicolumn{9}{|c|}{ Panel II: Brothers } \\
\hline \multirow[t]{4}{*}{ Stutter } & -0.137 & 0.059 & 0.100 & $-0.099 *$ & -0.042 & -0.032 & -0.015 & 0.082 & 0.119 \\
\hline & $(0.107)$ & $(0.115)$ & $(0.143)$ & $(0.056)$ & $(0.054)$ & $(0.078)$ & $(0.058)$ & $(0.071)$ & $(0.102)$ \\
\hline & {$[512]$} & {$[512]$} & {$[240]$} & [708] & [708] & {$[344]$} & [708] & [708] & [344] \\
\hline & \multicolumn{9}{|c|}{ Panel III: Sisters } \\
\hline \multirow[t]{3}{*}{ Stutter } & -0.048 & -0.113 & 0.023 & -0.054 & 0.074 & -0.019 & -0.033 & -0.061 & 0.066 \\
\hline & $(0.122)$ & $(0.124)$ & $(0.144)$ & $(0.059)$ & $(0.066)$ & $(0.069)$ & $(0.067)$ & $(0.079)$ & $(0.112)$ \\
\hline & {$[571]$} & {$[571]$} & {$[252]$} & [807] & [807] & {$[362]$} & [807] & [807] & [362] \\
\hline
\end{tabular}

$* * *$ Significant at $1 \%$ level $* *$ Significant at $5 \%$ level $*$ Significant at $10 \%$ level

Notes: All estimates were obtained using unweighted data from full siblings drawn from Waves I and III of the National Longitudinal Study of Adolescent Health. Standard errors, corrected for clustering on the family for OLS models, are in parentheses and sample sizes are in brackets. 
Table 7. Sensitivity of OLS Estimates to Controls for ADHD and Learning Disability

\begin{tabular}{|c|c|c|c|c|}
\hline & (1) & (2) & (3) & (4) \\
\hline & \multicolumn{4}{|c|}{ Panel I: Grade Point Average } \\
\hline Stutter & $\begin{array}{c}-0.090^{* * *} \\
(0.029)\end{array}$ & $\begin{array}{l}-0.021 \\
(0.029)\end{array}$ & $\begin{array}{c}-0.058^{* *} \\
(0.029)\end{array}$ & $\begin{array}{l}-0.006 \\
(0.028)\end{array}$ \\
\hline ADHD Scale & & $\begin{array}{c}-0.017^{* * *} \\
(0.001)\end{array}$ & & $\begin{array}{c}-0.015^{* * *} \\
(0.001)\end{array}$ \\
\hline Learning Disability & & & $\begin{array}{c}-0.360 * * * \\
(0.028)\end{array}$ & $\begin{array}{c}-0.283 * * * \\
(0.027)\end{array}$ \\
\hline \multirow[t]{2}{*}{ N } & 9,066 & 9,066 & 9,066 & 9,066 \\
\hline & \multicolumn{4}{|c|}{ Panel II: High School Graduation } \\
\hline Stutter & $\begin{array}{l}-0.017 \\
(0.015)\end{array}$ & $\begin{array}{l}0.0003 \\
(0.015)\end{array}$ & $\begin{array}{c}-0.009 \\
(0.015)\end{array}$ & $\begin{array}{c}0.004 \\
(0.015)\end{array}$ \\
\hline ADHD Scale & & $\begin{array}{c}-0.004 * * * \\
(0.0004)\end{array}$ & & $\begin{array}{c}-0.004 * * * \\
(0.0004)\end{array}$ \\
\hline Learning Disability & & & $\begin{array}{c}-0.094 * * * \\
(0.014)\end{array}$ & $\begin{array}{c}-0.075^{* * *} \\
(0.015)\end{array}$ \\
\hline \multirow[t]{2}{*}{ N } & 11,222 & 11,222 & 11,222 & 11,222 \\
\hline & \multicolumn{4}{|c|}{ Panel III: College Attendance } \\
\hline Stutter & $\begin{array}{c}-0.033^{* *} \\
(0.016)\end{array}$ & $\begin{array}{c}-0.012 \\
(0.015)\end{array}$ & $\begin{array}{c}-0.020 \\
(0.016)\end{array}$ & $\begin{array}{l}-0.005 \\
(0.015)\end{array}$ \\
\hline ADHD Scale & & $\begin{array}{c}-0.005^{* * *} \\
(0.001)\end{array}$ & & $\begin{array}{c}-0.004 * * * \\
(0.0006)\end{array}$ \\
\hline Learning Disability & & & $\begin{array}{c}-0.173^{* * *} \\
(.013)\end{array}$ & $\begin{array}{c}-0.151^{* * *} \\
(0.013)\end{array}$ \\
\hline $\mathrm{N}$ & 11,228 & 11,228 & 11,228 & 11,228 \\
\hline
\end{tabular}

$* * *$ Significant at $1 \%$ level $* *$ Significant at $5 \%$ level * Significant at $10 \%$ level Notes: All estimates were obtained using unweighted data drawn from Waves I and III of the National Longitudinal Study of Adolescent Health. Standard errors corrected for clustering on the school are in parentheses. 
Appendix Table 1. Sensitivity of OLS Estimates to Use of Stuttering Measure at Wave IV

\begin{tabular}{|c|c|c|c|c|}
\hline & $(1)$ & $(2)$ & (3) & (4) \\
\hline & \multicolumn{4}{|c|}{ Panel I: Grade Point Average } \\
\hline Stutter & $\begin{array}{l}-0.043 \\
(0.045)\end{array}$ & $\begin{array}{c}0.015 \\
(0.045)\end{array}$ & $\begin{array}{c}-0.003 \\
(0.045)\end{array}$ & $\begin{array}{c}0.040 \\
(0.045)\end{array}$ \\
\hline ADHD Scale & & $\begin{array}{c}-0.017^{* * *} \\
(0.001)\end{array}$ & & $\begin{array}{c}-0.015^{* * *} \\
(0.001)\end{array}$ \\
\hline Learning Disability & & & $\begin{array}{c}-0.378 * * * \\
(0.027)\end{array}$ & $\begin{array}{c}-0.296 * * * \\
(0.026)\end{array}$ \\
\hline \multirow[t]{2}{*}{$\mathrm{N}$} & 8,970 & 8,970 & 8,970 & 8,970 \\
\hline & \multicolumn{4}{|c|}{ Panel II: High School Graduation } \\
\hline Stutter & $\begin{array}{c}-0.040 * * \\
(0.020)\end{array}$ & $\begin{array}{l}-0.026 \\
(0.020)\end{array}$ & $\begin{array}{l}-0.030 \\
(0.020)\end{array}$ & $\begin{array}{l}-0.020 \\
(0.021)\end{array}$ \\
\hline ADHD Scale & & $\begin{array}{c}-0.004 * * * \\
(0.0004)\end{array}$ & & $\begin{array}{c}-0.003 * * * \\
(0.0005)\end{array}$ \\
\hline Learning Disability & & & $\begin{array}{c}-0.093^{* * *} \\
(0.016)\end{array}$ & $\begin{array}{c}-0.075 * * * \\
(0.017)\end{array}$ \\
\hline \multirow[t]{2}{*}{$\mathrm{N}$} & 10,977 & 10,977 & 10,977 & 10,977 \\
\hline & \multicolumn{4}{|c|}{ Panel III: College Attendance } \\
\hline Stutter & $\begin{array}{c}-0.059 * * \\
(0.023)\end{array}$ & $\begin{array}{l}-0.043^{*} \\
(0.023)\end{array}$ & $\begin{array}{c}-0.038 * \\
(0.023)\end{array}$ & $\begin{array}{l}-0.029 \\
(0.022)\end{array}$ \\
\hline ADHD Scale & & $\begin{array}{c}-0.004 * * * \\
(0.0005)\end{array}$ & & $\begin{array}{c}-0.003 * * * \\
(0.0005)\end{array}$ \\
\hline Learning Disability & & & $\begin{array}{c}-0.200 * * * \\
(0.014)\end{array}$ & $\begin{array}{c}-0.183 * * * \\
(0.014)\end{array}$ \\
\hline $\mathrm{N}$ & 10,977 & 10,977 & 10,977 & 10,977 \\
\hline
\end{tabular}

$* * *$ Significant at $1 \%$ level $* *$ Significant at $5 \%$ level $*$ Significant at $10 \%$ level Notes: All estimates were obtained using unweighted data drawn from Waves I and IV of the National Longitudinal Study of Adolescent Health. Standard errors corrected for clustering on the school are in parentheses. 


\begin{tabular}{|c|c|c|c|c|}
\hline & $(1)$ & $(2)$ & (3) & (4) \\
\hline & \multicolumn{4}{|c|}{ Panel I: Grade Point Average } \\
\hline Stutter & $\begin{array}{c}-0.085 * * * \\
(0.027)\end{array}$ & $\begin{array}{c}-0.078 * * * \\
(0.028)\end{array}$ & $\begin{array}{c}-0.057^{* *} \\
(0.028)\end{array}$ & $\begin{array}{c}-0.062 * * \\
(0.028)\end{array}$ \\
\hline Control for Anxiety Index? & No & Yes & No & Yes \\
\hline Control for Neuroticism? & No & No & Yes & Yes \\
\hline \multirow[t]{2}{*}{$\mathrm{N}$} & 10,834 & 10,834 & 10,834 & 10,834 \\
\hline & \multicolumn{4}{|c|}{ Panel II: High School Graduation } \\
\hline Stutter & $\begin{array}{c}-0.029 * * \\
(0.013)\end{array}$ & $\begin{array}{c}-0.026 * * \\
(0.013)\end{array}$ & $\begin{array}{l}-0.020 \\
(0.013)\end{array}$ & $\begin{array}{l}-0.020 \\
(0.013)\end{array}$ \\
\hline Control for Anxiety Index? & No & Yes & No & Yes \\
\hline Control for Neuroticism? & No & No & Yes & Yes \\
\hline \multirow[t]{2}{*}{$\mathrm{N}$} & 13,549 & 13,549 & 13,549 & 13,549 \\
\hline & \multicolumn{4}{|c|}{ Panel III: College Attendance } \\
\hline Stutter & $\begin{array}{c}-0.046 * * * \\
(0.014)\end{array}$ & $\begin{array}{c}-0.040 * * * \\
(0.014)\end{array}$ & $\begin{array}{c}-0.029 * * \\
(0.014)\end{array}$ & $\begin{array}{c}-0.031 * * \\
(0.014)\end{array}$ \\
\hline Control for Anxiety Index? & No & Yes & No & Yes \\
\hline Control for Neuroticism? & No & No & Yes & Yes \\
\hline $\mathrm{N}$ & 13,549 & 13,549 & 13,549 & 13,549 \\
\hline
\end{tabular}

\footnotetext{
Significant at $1 \%$ level $* *$ Significant at $5 \%$ level $*$ Significant at $10 \%$ level
} Notes: All estimates were obtained using unweighted data drawn from Waves I, III, and IV of the National Longitudinal Study of Adolescent Health. Standard errors corrected for clustering on the school are in parentheses. 


\begin{tabular}{|c|c|c|c|c|c|}
\hline PPVT Score & $\begin{array}{c}-0.006 * * * \\
(0.001)\end{array}$ & $\begin{array}{l}\text { Parent Attend Grad } \\
\text { School }\end{array}$ & $\begin{array}{l}-0.099 \\
(0.091)\end{array}$ & $\begin{array}{l}\text { Closeness to } \\
\text { Mother -- } 1\end{array}$ & $\begin{array}{c}-5.36 * * * \\
(0.418)\end{array}$ \\
\hline Age 20 & $\begin{array}{c}0.051 \\
(0.076)\end{array}$ & Black & $\begin{array}{c}0.062 \\
(0.060)\end{array}$ & $\begin{array}{l}\text { Closeness to } \\
\text { Mother -- } 2\end{array}$ & $\begin{array}{l}-0.094 \\
(0.200)\end{array}$ \\
\hline Age 21 & $\begin{array}{c}0.021 \\
(0.053)\end{array}$ & Asian & $\begin{array}{c}0.027 \\
(0.081)\end{array}$ & $\begin{array}{l}\text { Closeness to } \\
\text { Mother -- } 4\end{array}$ & $\begin{array}{l}-0.137 \\
(0.125)\end{array}$ \\
\hline Age 23 & $\begin{array}{c}0.021 \\
(0.053)\end{array}$ & Hispanic/Other & $\begin{array}{c}0.021 \\
(0.063)\end{array}$ & $\begin{array}{l}\text { Closeness to } \\
\text { Mother -- } 5\end{array}$ & $\begin{array}{l}-0.175 \\
(0.109)\end{array}$ \\
\hline Age 24 & $\begin{array}{l}-0.002 \\
(0.056)\end{array}$ & Native American & $\begin{array}{c}0.191 \\
(0.128)\end{array}$ & $\begin{array}{l}\text { Closeness to } \\
\text { Father -- } 1\end{array}$ & $\begin{array}{c}4.74 \\
(4.00)\end{array}$ \\
\hline Age 25 & $\begin{array}{c}0.030 \\
(0.080)\end{array}$ & Catholic & $\begin{array}{l}-0.058 \\
(0.062)\end{array}$ & $\begin{array}{l}\text { Closeness to } \\
\text { Father -- } 2\end{array}$ & $\begin{array}{c}0.275 \\
(0.240)\end{array}$ \\
\hline Age 26 & $\begin{array}{l}-0.197 \\
(0.203)\end{array}$ & Baptist or Methodist & $\begin{array}{l}-0.085 \\
(0.058)\end{array}$ & $\begin{array}{l}\text { Closeness to } \\
\text { Father -- } 4\end{array}$ & $\begin{array}{c}0.055 \\
(0.150)\end{array}$ \\
\hline Age 27 & $\begin{array}{c}0.132 \\
(0.352)\end{array}$ & Other Christian & $\begin{array}{l}-0.046 \\
(0.063)\end{array}$ & $\begin{array}{l}\text { Closeness to } \\
\text { Father -- } 5\end{array}$ & $\begin{array}{c}0.044 \\
(0.131)\end{array}$ \\
\hline Married & $\begin{array}{c}0.014 \\
(0.045)\end{array}$ & $\begin{array}{l}\text { Non-Christian } \\
\text { Religion }\end{array}$ & $\begin{array}{l}-0.145 \\
(0.101)\end{array}$ & $\begin{array}{l}\text { Mother disappoint } \\
\text { if no grad HS -- } 1\end{array}$ & $\begin{array}{c}0.048 \\
(0.082)\end{array}$ \\
\hline Log (Income) & $\begin{array}{c}-0.072 * * \\
(0.030)\end{array}$ & Height & $\begin{array}{c}0.008 \\
(0.006)\end{array}$ & $\begin{array}{l}\text { Mother disappoint } \\
\text { if no grad HS -- } 2\end{array}$ & $\begin{array}{l}0.169 * * \\
(0.080)\end{array}$ \\
\hline $\begin{array}{l}\text { Parent Never } \\
\text { Married }\end{array}$ & $\begin{array}{c}-0.197 * * \\
(0.096)\end{array}$ & Weight & $\begin{array}{c}0.000 \\
(0.001)\end{array}$ & $\begin{array}{l}\text { Mother disappoint } \\
\text { if no grad HS -- } 4\end{array}$ & $\begin{array}{c}0.021 \\
(0.061)\end{array}$ \\
\hline $\begin{array}{l}\text { Parents } \\
\text { Divorced }\end{array}$ & $\begin{array}{l}-0.098 \\
(0.071)\end{array}$ & $\begin{array}{l}\text { Number of } \\
\text { biological children }\end{array}$ & $\begin{array}{c}0.001 \\
(0.013)\end{array}$ & $\begin{array}{l}\text { Mother disappoint } \\
\text { if no grad HS -- } 5\end{array}$ & $\begin{array}{l}0.093^{*} \\
(0.052)\end{array}$ \\
\hline $\begin{array}{l}\text { Parents } \\
\text { Separated }\end{array}$ & $\begin{array}{l}-0.160 * \\
(0.097)\end{array}$ & $\begin{array}{l}\text { Whether has an } \\
\text { older sibling }\end{array}$ & $\begin{array}{c}0.023 \\
(0.059)\end{array}$ & $\begin{array}{l}\text { Mother disappoint } \\
\text { if no grad coll -- } 1\end{array}$ & $\begin{array}{c}0.103 \\
(0.145)\end{array}$ \\
\hline $\begin{array}{l}\text { Parent } \\
\text { Widowed }\end{array}$ & $\begin{array}{l}-0.105 \\
(0.106)\end{array}$ & Female & $\begin{array}{c}-0.203^{* * *} \\
(0.0044)\end{array}$ & $\begin{array}{l}\text { Mother disappoint } \\
\text { if no grad coll -- } 2\end{array}$ & $\begin{array}{c}0.198 \\
(0.179)\end{array}$ \\
\hline $\begin{array}{l}\text { Parent Complete } \\
\text { High School }\end{array}$ & $\begin{array}{c}0.060 \\
(0.057)\end{array}$ & Very Attractive & $\begin{array}{l}-0.097^{*} \\
(0.058)\end{array}$ & $\begin{array}{l}\text { Mother disappoint } \\
\text { if no grad coll -- } 4\end{array}$ & $\begin{array}{c}0.120 \\
(0.130)\end{array}$ \\
\hline $\begin{array}{l}\text { Parent Attend } \\
\text { Trade School }\end{array}$ & $\begin{array}{l}-0.022 \\
(0.078)\end{array}$ & Attractive & $\begin{array}{l}-0.062 \\
(0.040)\end{array}$ & $\begin{array}{l}\text { Mother disappoint } \\
\text { if no grad coll -- } 5\end{array}$ & $\begin{array}{c}0.022 \\
(0.110)\end{array}$ \\
\hline $\begin{array}{l}\text { Parent Attend Som } \\
\text { College }\end{array}$ & $\begin{array}{l}-0.031 \\
(0.065)\end{array}$ & Unattractive & $\begin{array}{c}0.118 \\
(0.075)\end{array}$ & $\mathrm{N}$ & 13,333 \\
\hline $\begin{array}{l}\text { Parent Complete } \\
\text { College }\end{array}$ & $\begin{array}{l}-0.079 \\
(0.074)\end{array}$ & Very Unattractive & $\begin{array}{l}-0.024 \\
(0.134)\end{array}$ & & \\
\hline
\end{tabular}

*** Significant at $1 \%$ level ** Significant at $5 \%$ level * Significant at $10 \%$ level Notes: All estimates were obtained using unweighted data drawn from Waves I and III of the National Longitudinal Study of Adolescent Health. Standard errors are in parentheses. 
Appendix Table 4. Cross-Tabulations of Stutter with ADHD and Learning Disability

\begin{tabular}{|c|c|c|c|c|}
\hline \multirow{5}{*}{ Stutter } & & \multicolumn{2}{|c|}{ ADHD Scale } & \multirow[b]{2}{*}{ Total N } \\
\hline & & $\geq 80$ th percentile & $<80$ th percentile & \\
\hline & Yes & 278 & 483 & 761 \\
\hline & No & 2079 & 8,388 & 10,467 \\
\hline & \multirow[t]{3}{*}{ Total N } & 2,357 & 8,871 & 11,228 \\
\hline & & \multicolumn{2}{|c|}{ Learning Disability } & \\
\hline \multirow{4}{*}{ Stutter } & & Yes & No & Total N \\
\hline & Yes & 163 & 598 & 761 \\
\hline & No & 1,189 & 9,278 & 10,467 \\
\hline & Total N & 1,352 & 9,876 & 11,228 \\
\hline
\end{tabular}

Notes: Sample sizes generated using cross-tabulations from Wave III of the National Longitudinal Study of Adolescent Health 